\title{
PERBANDINGAN DAYA ANTARA LAMPU BIASA DENGAN LAMPU TERJADWAL OTOMATIS DI GEDUNG GRIYA LEGITA UNIVERSITAS PERTAMINA
}

\author{
Adam Marsono Putra \\ Fakultas Sains dan Komputer, Program Studi Ilmu Komputer \\ Universitas Pertamina \\ Email: adammarsonoputra@gmail.com \\ Megandi \\ Fakultas Sains dan Komputer, Program Studi Ilmu Komputer \\ Universitas Pertamina \\ Email: me.gandi2471@gmail.com \\ Nugi Gahara Yasa \\ Fakultas Sains dan Komputer, Program Studi Ilmu Komputer \\ Universitas Pertamina \\ Email: Nugigy@gmail.com \\ Shelvy Intan Soraya \\ Fakultas Sains dan Komputer, Program Studi Ilmu Komputer \\ Universitas Pertamina \\ Email: Shelvyyy@gmail.com \\ Sahrul \\ Fakultas Sains dan Komputer, Program Studi Ilmu Komputer \\ Universitas Pertamina \\ Email: hsahrul@null.net \\ Meredita Susanty \\ Fakultas Sains dan Komputer, Program Studi Ilmu Komputer \\ Universitas Pertamina \\ Email: mereditasusanty@gmail.com \\ Erwin Setiawan \\ Fakultas Sains dan Komputer, Program Studi Ilmu Komputer \\ Universitas Pertamina \\ Email: erwin.setiaw4n@gmail.com
}

\begin{abstract}
ABSTRAK
Pada artikel ini akan dibahas analisis perbandingan konsumsi listrik dari penggunaan lampu secara manual dan lampu secara terjadwal otomatis. Penggunaan lampu secara manual ialah lampu dinyalakan dan dimatikan menggunakan saklar tanpa adanya batasan waktu, sedangkan penggunaan lampu secara terjadwal otomatis ialah penggunaan lampu yang hanya akan menyala dan mati sesuai dengan jadwal penggunaan ruangan yang terdaftar. Adapun tujuan dari dibuatnya artikel ini adalah untuk mengetahui kelayakan dari metode penggunaan lampu secara terjadwal otomatis dengan menganalisis apakah penggunaan lampu dengan metode tersebut dapat mengurangi konsumsi listrik atau tidak. Metode yang kami gunakan adalah perbandingan kuantitatif, dengan mengumpulkan data yang diperlukan untuk mendapatkan pengeluaran energi listrik untuk penerangan di gedung Griya Legita, kami membandingkan pengeluaran energi listrik ketika penggunaan lampu tidak terjadwal dan ketika penggunaan lampu dibuat terjadwal dengan sistem otomatis sepanjang Januari 2018. Hasil menunjukkan sistem lampu secara terjadwal otomatis memberikan efisiensi bekisar antara 1,5\% hingga 94\%. Pada bagian akhir dari artikel ini disimpulkan bahwa penggunaan lampu secara terjadwal otomatis dapat mengurangi konsumsi daya listrik di Gedung Griya Legita Universitas Pertamina meski tidak signifikan dikarenakan beberapa asumsi.
\end{abstract}

Kata kunci: lampu; gedung swasta; penggunaan listrik; perbandingan. 


\section{ABSTRACT}

In this article, we discussed about comparison analysis of electrical consumption between manual lamps and lamps which have active schedule. What we mean by manual lamps are lamps that need to be turned on and off using electrical switch without any time restriction, and what we mean by schedule-based lamps are lamps that already have active schedule and will automatically turned on only when the time is its active schedule. The purpose of this article creation is to know whether it is worth it to implement schedule-based lamp utilization method by analyzing its efficiency towards lamps electrical consumption. The method we used to run this research is quantitative comparison, by collecting data needed to calculate the electrical energy utilization of lamps in Griya Legita building, we then compare the electrical energy usage when schedule-based lamps system is not implemented and electrical energy usage when schedulebased lamps system is implemented throughout January 2018. The result showed that schedule-based lamps system would give efficiency ranging from 1,5\% to 94\%. In the end of this article, it was concluded that schedule-based lamps system can decrease electrical energy usage in Griya Legita, even though the decrease was not really significant due to some assumptions.

Keywords: lamp; private building; electricity usage; comparison.

\section{PENDAHULUAN}

Pemborosan energi yang terjadi di Indonesia tidak bisa dikatakan kecil. Menurut kajian PT Energy Management Indonesia (EMI), rata-rata pemborosan energi di gedung perkantoran swasta mencapai $20 \%$. Pemborosan ini jauh lebih besar apabila dibandingkan dengan pemborosan energi rumah tangga yang hanya $10 \%$. Salah satu penyebab terjadinya pemborosan listrik adalah kebiasaan buruk dalam menggunakan lampu, yaitu membiarkan lampu tetap menyala saat tidak lagi digunakan [1]. Meskipun lampu tidak termasuk dalam peralatan dengan konsumsi listrik tertinggi [2] lampu tetap dikategorikan sebagai peralatan dengan kebutuhan listrik yang tinggi yakni mencapai 30\% dari total konsumsi listrik [3].

Penggunaan listrik di Indonesia permintaannya terus meningkat, baik untuk kegiatan rumah tangga, perkantoran, maupun untuk industri. Namun, pasokan listrik yang dihasilkan oleh pembangkit listrik belum mampu memenuhi permintaan penggunaan yang terus meningkat tersebut [4]. Upaya pemerintah untuk mengurangi penggunaan listrik khususnya lampu adalah mempromosikan program earth hour yaitu mematikan lampu selama satu jam. Program tersebut terbukti menghemat listrik sebesar 169,9 MW pada tahun 2018 [5]. Pemerintah juga menginisiasikan gerakan "Potong 10\%", gerakan ini menyasar para pelanggan listik rumah tangga untuk melakukan penghematan dengan melakukan hal-hal kecil seperti mematikan lampu saat keluar ruangan, mematikan televisi saat tidak digunakan, hingga menggunakan lampu hemat listrik/LED. Gerakan potong $10 \%$ ini dapat menghemat listrik yang setara dengan pembangungan listrik tenaga uap berkapasitas 900MW [6][7].

Selain upaya pemerintah di atas, upaya yang mungkin dapat dilakukan untuk mengurangi konsumsi listrik dari lampu yakni dengan menggunakan metode penggunaan lampu secara terjadwal otomatis, yaitu lampu hanya menyala (dengan otomatis) apabila ruangan digunakan atau terdaftar dalam jadwal peminjaman ruangan. Penelitian untuk menganalisis konsumsi energi pada beberapa peralatan termasuk lampu pernah dilakukan di Universitas Indonesia. Hasil temuan dari penelitian tersebut menyatakan bahwa dengan mengganti jenis lampu TL ke lampu LED dapat mengurangi konsumsi energi pada sebuah bangunan [8]. Pada penelitian ini, penulis menganalisis perbandingan penggunaan lampu secara manual dan penggunaan lampu secara terjadwal otomatis, dengan konsumsi listrik dari lampu pada gedung Griya Legita, Universitas Pertamina sebagai objek analisisnya. Saat ini gedung Griya Legita menggunakan metode penggunaan lampu secara manual, lampu dinyalakan setiap hari Senin sampai dengan hari Sabtu mulai pukul 06.00 sampai dengan 21.00 WIB. Tabel 1 berikut ini menunjukkan konsumsi listrik Universitas Pertamina pada bulan Januari 2018.

Tabel 1. Konsumsi ListriK Universitas Pertamina Januari 2018

\begin{tabular}{clrc}
\hline NO & \multicolumn{1}{c}{ TENANT NAME } & KWH & \% \\
\hline$\underline{A}$ & FACILITY & & \\
1 & KOLAM RENANG & $19.624,00$ & $6,1 \%$ \\
2 & FITNES & $3.640,00$ & $1,1 \%$ \\
3 & GOR-I & $15.695,00$ & $4,8 \%$ \\
4 & GOR-II & $13.576,00$ & $4,2 \%$ \\
5 & LAPANGAN BOLA & $2.196,00$ & $0,7 \%$ \\
6 & PSR-1 & $25.048,00$ & $7,7 \%$ \\
7 & PSR-2 & $23.232,00$ & $7,2 \%$
\end{tabular}




\begin{tabular}{rlrc}
\hline $\boldsymbol{N O}$ & \multicolumn{1}{c}{ TENANT NAME} & $\boldsymbol{K W H}$ & \% \\
\hline & \multicolumn{1}{c}{ SUB TOTAL } & $103.011,00$ & $31,8 \%$ \\
$B$ & OFFICE \& TRAINING CENTER & & \\
1 & PLC GL-IA (PERALATAN) & $13.541,00$ & $4,2 \%$ \\
2 & PLC GL-IB (PENERANGAN) & $4.702,00$ & $1,5 \%$ \\
3 & PLC GL-IIA (PERALATAN) & $27.458,00$ & $8,5 \%$ \\
4 & PLC GL-IIB (PENERANGAN) & $58.813,00$ & $18,1 \%$ \\
5 & TC-III (PENERANGAN) & $23.986,00$ & $7,4 \%$ \\
6 & TC-III (PERALATAN) & $7.109,00$ & $2,2 \%$ \\
7 & PWP & $16.904,00$ & $5,2 \%$ \\
8 & R-1 (PAJ) & $13.816,00$ & $4,3 \%$ \\
8 & R-1 (BUMN) & $1.310,00$ & $0,4 \%$ \\
9 & R-1 (ILUGAS) & $12.466,00$ & $3,8 \%$ \\
10 & R-8A (Fondation) & $16.199,00$ & $5,0 \%$ \\
11 & R-8B (Fondation) & $14.698,00$ & $4,5 \%$ \\
& SUB TOTAL & $211.002,00$ & $65,1 \%$ \\
C & COMMON AREA & & \\
1 & Penerangan Jalan + Taman & $5.937,00$ & $1,8 \%$ \\
2 & Peralatan STP / IPAL & $4.090,00$ & $1,3 \%$ \\
& SUB TOTAL & $10.027,00$ & $3,1 \%$ \\
& TOTAL (A+B+C) & $324.040,00$ & $100,0 \%$ \\
\hline
\end{tabular}

Konsumsi listrik dari lampu ditunjukan Tabel 1 bagian B Office \& Training Center No. 2 dan 4 dengan total persentase mencapai 19,6 persen, yang artinya konsumsi listrik dari lampu menjadi yang paling besar. Dari data konsumsi listrik tersebut, penulis akan menganalisis perbandingan konsumsi listrik apabila gedung Griya Legita menggunakan lampu secara terjadwal otomatis.

Adapun tujuan dari penelitian ini adalah untuk mengetahui kelayakan dari metode penggunaan lampu secara terjadwal otomatis. Apabila hasil dari analisis perbandingan membuktikan bahwa penggunaan lampu secara terjadwal otomatis dapat mengurangi konsumsi listrik, maka dapat disimpulkan bahwa salah satu upaya mengurangi konsumsi listrik dapat dilakukan dengan mengubah metode penggunaan lampu ke terjadwal otomatis.

\section{STUDI PUSTAKA}

\subsection{Daya}

Daya merupakan banyaknya energi yang dihasilkan suatu gaya dalam satuan waktu [9]. Dalam persamaan matematika dinyatakan sebagai berikut:

$$
\begin{aligned}
& P_{\text {rata-rata }}=\frac{W}{\Delta t} \\
& \mathrm{~W}=\text { Energi/Usaha } \\
& \mathrm{P}=\text { Daya } \\
& \Delta t=\text { Rentang waktu }
\end{aligned}
$$

Dalam konteks ini, energi merupakan energi listrik yang digunakan oleh para lampu, sementara daya merupakan daya masing-masing lampu yang digunakan dalam penerangan gedung, dan rentang waktu adalah lama waktu penggunaan lampu. Persamaan ini akan menjadi persamaan utama dalam penelitian ini.

\subsection{Sistem lampu otomatis}

Sistem lampu otomatis adalah sistem penggunaan lampu yang penggunaannya tidak hanya berdasarkan interaksi pengguna dengan saklar lampu. Sistem ini menggunakan sistem kendali tambahan, seperti sistem kendali jarak jauh, sistem sensor, ataupun sisten jadwal [10]. Sistem lampu terjadwal otomatis berbasis komputer dengan kendali terprogram adalah sistem penerangan atau penggunaan lampu yang nyala dan matinya dikendalikan jarak jauh dengan jadwal yang ditentukan dan diprogram lewat komputer [10]. 


\section{METODOLOGI PENELITIAN}

Pendekatan yang digunakan pada penelitian ini adalah penelitian kuantitatif. Penelitian kuantitatif adalah suatu proses menemukan pengetahuan yang menggunakan data berupa angka sebagai alat menganalisis keterangan mengenai apa yang ingin diketahui [11]. Data kuantitatif yang diperoleh merupakan data penggunaan listrik, peminjaman ruangan, jumlah lampu, dan daya tiap jenis lampu.

Penelitian yang dilakukan hanya mencakup konsumsi energi listrik di gedung Griya Legita Universitas Pertamina pada sektor penerangan dalam satu bulan. Ada dua jenis konsumsi daya dan konsumsi energi penggunaan lampu yang akan dianalisis, lampu dengan sistem lama dan lampu dengan sistem nyala otomatis. Lampu dengan sistem lama merupakan sistem penggunaan lampu yang menyala selama lampu tersebut tidak dimatikan. Sedangkan untuk lampu terjadwal otomatis adalah lampu yang menyala hanya pada jam tertentu yang telah dijadwalkan dan terintegrasi dengan sistem peminjaman dan penjadwalan ruangan. Diagram alir penelitian ini seperti yang ditunjukkan di Gambar $\mathbf{1}$ berikut ini:

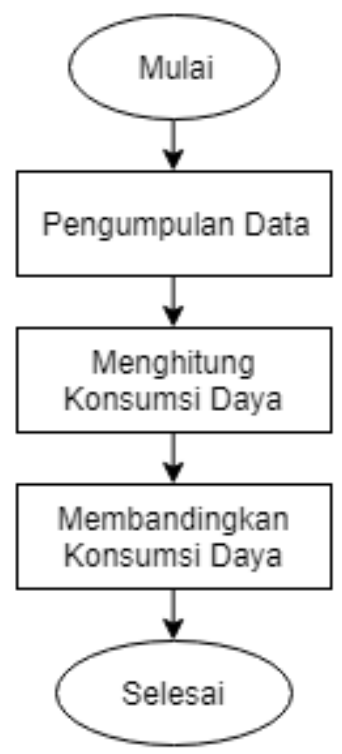

\section{Gambar 1. Diagram Alir Proses Penelitian}

Langkah awal pada penelitian ini adalah pengumpulan data tentang penggunaan listrik, daftar peminjaman ruangan, jumlah lampu yang ada di tiap ruangan, dan daya tiap jenis lampu. Data penggunaan listrik, peminjaman ruangan, dan daya tiap jenis lampu diperoleh dari Fungsi Sarana dan Prasarana Universitas Pertamina. Sedangkan jumlah lampu diperoleh dengan menghitung jumlah lampu di setiap lantai.

Langkah kedua adalah menghitung jumlah konsumsi daya listrik penggunaan lampu di gedung Griya Legita Universitas Pertamina selama Januari 2018. Perhitungan konsumsi daya terdapat dua jenis, pertama konsumsi daya dengan sistem penggunaan lampu yang lama dan yang kedua adalah konsumsi daya dengan lampu otomatis. Konsumsi daya listrik lampu diperoleh dengan menggunakan persamaan-persamaan berikut ini:

$\Sigma$ (daya per lampu $x$ kuantitas lampu $x$ durasi penggunaan tiap ruangan)

$\Sigma$ (daya per lampu $x$ kuantitas lampu $x 14$ )

Langkah ketiga adalah menghitung persentase efektifitas penggunaan lampu sistem lama dengan penggunaan lampu terjadwal otomatis. Persentase efektifitas sistem penggunaan lampu sistem lama dan terjadwal otomatis diperoleh dengan menggunakan persamaan-persamaan berikut ini:

$$
\begin{aligned}
& \text { (penggunaan ruangan terjadwal + penggunaan rungan tidak terjadwal + koridor) } x \\
& 100 \% \\
& \text { (penggunaan ruangan terjadwal }+ \text { koridor) } x 100 \%
\end{aligned}
$$


Setelah melalui proses perhitungan konsumsi daya listrik dan efektifitas penggunaan lampu, langkah terakhir pada penelitian ini adalah membandingkan penggunaan lampu dengan sistem yang lama dengan sistem lampu terjadwal otomatis.

\section{HASIL DAN PEMBAHASAN}

\subsection{Pengumpulan Data}

\subsubsection{Daya Lampu}

Data kami dapatkan dengan cara mendatangi pihak rektorat, untuk menanyakan daya masing-masing jenis lampu yang ada. Didapat bahwa ada 3 jenis lampu:

a) Lampu bulb dengan daya 10,5 watt

b) Lampu LED dengan daya 18 watt

c) Lampu kuning dengan daya 10.5 watt

\subsubsection{Jumlah Lampu Per Ruangan}

Tabel 2. Jumlah lampu di lantai 1, 2, dan 3

\begin{tabular}{lccccccc}
\hline \multicolumn{1}{c}{ Jenis } & \multicolumn{6}{c}{ Ruangan } & \multirow{2}{*}{ Lt. 3 } \\
\cline { 2 - 8 } Lampu & $\mathbf{2 1 0 1 . 1}$ & $\mathbf{2 1 0 1 . 2}$ & $\mathbf{2 1 0 1 . 3}$ & $\mathbf{2 2 0 1 . 1}$ & $\mathbf{2 2 0 1 . 2}$ & $\mathbf{2 2 0 1 . 3}$ & \\
\hline Bulb & 15 & 14 & 14 & 15 & 14 & 14 & 18 \\
Kotak & & & & & & & 36 \\
Kuning & & & & & & & \\
\hline
\end{tabular}

Tabel 3. Jumlah lampu di lantai 4

\begin{tabular}{lccccccc}
\hline \multicolumn{1}{c}{ Jenis } & \multicolumn{8}{c}{ Ruangan } & \multirow{2}{c}{} \\
\cline { 2 - 8 } Lampu & $\mathbf{2 4 0 1}$ & $\mathbf{2 4 0 2}$ & $\mathbf{2 4 0 3}$ & $\mathbf{2 4 0 4}$ & $\mathbf{2 4 0 5}$ & $\mathbf{2 4 0 6}$ & $\mathbf{2 4 0 7}$ \\
\hline Bulb & 5 & 6 & 2 & 3 & 3 & 4 & 2 \\
Kotak & 6 & & 12 & 4 & 4 & 6 & 4 \\
Kuning & & & & & & & \\
\hline
\end{tabular}

Tabel 4. Jumlah lampu di lantai 5

\begin{tabular}{lccccccc}
\hline \multirow{2}{*}{ Jenis } & \multicolumn{8}{c}{ Ruangan } & \\
\cline { 2 - 8 } \multicolumn{1}{c}{ Lampu } & $\mathbf{2 5 0 1}$ & $\mathbf{2 5 0 2}$ & $\mathbf{2 5 0 3}$ & $\mathbf{2 5 0 4}$ & $\mathbf{2 5 0 5}$ & $\mathbf{2 5 0 6}$ & $\mathbf{2 5 0 7}$ \\
\hline Bulb & 2 & 3 & 4 & 3 & 3 & 3 & 2 \\
Kotak & 6 & 6 & 8 & 6 & 6 & 6 & 4 \\
Kuning & & & & & & & \\
\hline
\end{tabular}

Tabel 5. Jumlah lampu di lantai 6

\begin{tabular}{lccccccc}
\hline \multicolumn{1}{c}{ Jenis } & \multicolumn{8}{c}{ Ruangan } & \multirow{2}{c}{ Lampu } \\
\cline { 2 - 8 } \multicolumn{1}{c}{} & $\mathbf{2 6 0 1}$ & $\mathbf{2 6 0 2}$ & $\mathbf{2 6 0 3}$ & $\mathbf{2 6 0 4}$ & $\mathbf{2 6 0 5}$ & $\mathbf{2 6 0 6}$ & $\mathbf{2 6 0 7}$ \\
\hline Bulb & 2 & 3 & 4 & 3 & 3 & 3 & 2 \\
Kotak & 6 & 6 & 8 & 6 & 6 & 6 & 4 \\
Kuning & & & & & & & \\
\hline
\end{tabular}

Tabel 6. Jumlah lampu di lantai 7

\begin{tabular}{lccccccc}
\hline Jenis & \multicolumn{8}{c}{ Ruangan } & \\
\cline { 2 - 8 } Lampu & $\mathbf{2 7 0 1}$ & $\mathbf{2 7 0 2}$ & $\mathbf{2 7 0 3}$ & $\mathbf{2 7 0 4}$ & $\mathbf{2 7 0 5}$ & $\mathbf{2 7 0 6}$ & $\mathbf{2 7 0 7}$ \\
\hline Bulb & 2 & 3 & 4 & 3 & 3 & 3 & 2 \\
Kotak & 6 & 6 & 8 & 6 & 6 & 6 & 4 \\
Kuning & & & & & & & \\
\hline
\end{tabular}

Tabel 7. Jumlah lampu di lantai 8 dan 9

\begin{tabular}{|c|c|c|c|c|c|c|c|c|}
\hline \multirow{2}{*}{$\begin{array}{c}\text { Jenis } \\
\text { Lampu }\end{array}$} & \multicolumn{6}{|c|}{ Ruangan } & \multirow[b]{2}{*}{2807} & \multirow[b]{2}{*}{ Lt. 9} \\
\hline & 2801 & 2802 & 2803 & 2804 & 2805 & 2806 & & \\
\hline Bulb & 2 & 3 & 4 & 3 & 3 & 3 & 2 & 121 \\
\hline Kotak & 6 & 6 & 8 & 6 & 6 & 6 & 4 & \\
\hline Kuning & & & & & & & & 6 \\
\hline
\end{tabular}




\subsubsection{Pemakaian Ruangan}

Data kami dapatkan dengan cara meminta data ke pihak rektorat, data tidak lengkap, beberapa data lama hilang/dihapus. Berikut adalah data pemakaian ruangan dalam jam pada bulan januari.

Tabel 9. Data waktu penggunaan ruangan lantai 1 sampai sebagian lantai 4

\begin{tabular}{cccccccc}
\hline Ruang & Jam Pakai & Ruang & Jam Pakai & Ruang & Jam Pakai & Ruang & Jam Pakai \\
\hline 2101.1 & 188 & 2406 & 118 & 2604 & 121 & 2802 & 56 \\
2101.2 & 175 & 2407 & 44.5 & 2605 & 97.5 & 2803 & 113.5 \\
2101.3 & 164.5 & 2501 & 112 & 2606 & 117 & 2804 & 105 \\
2201.1 & 147.5 & 2502 & 119.5 & 2607 & 94 & 2805 & 44 \\
2201.2 & 147 & 2503 & 133.5 & 2701 & 55 & 2806 & 49 \\
2201.3 & 153.5 & 2504 & 119 & 2702 & 97.5 & 2807 & 89 \\
Lantai 3 & 1695 & 2505 & 104 & 2703 & 129 & Lantai 9 & 246 \\
2401 & 143.5 & 2506 & 103.5 & 2704 & 126.5 & & \\
2402 & 338 & 2507 & 109.5 & 2705 & 115 & & \\
2403 & 338 & 2601 & 95 & 2706 & 106 & & \\
2404 & 137.5 & 2602 & 115 & 2707 & 58 & & \\
2405 & 120 & 2603 & 121 & 2801 & 44 & & \\
\hline
\end{tabular}

\subsubsection{Pengeluaran Daya Lampu Per Bulan}

Kami dapatkan dengan meminta data ke pihak rektorat, data tidak lengkap, beberapa data baru belum tersedia. Data bernilai 63.515 .000 watt/hour.

\subsubsection{Penggunaan Lampu Non-Ruangan}

Kami dapatkan dengan bertanya ke pihak satpam tentang jam nyala lampu. Didapatkan laporan bahwa jam nyala lampu adalah jam 6.00 hingga jam 20.00 WIB.

\subsubsection{Kuantitas Lampu Non-Ruangan}

Kami dapatkan bahwa terdapat total 459 lampu bulb berdasarkan perhitungan manual.

\subsection{Analisis dan Pengolahan Data}

a) Kami kalikan daya per jenis lampu dengan kuantitas untuk jenis lampu bersesuaian pada tiap ruangannya, sehingga didapat pengeluaran daya listrik penerangan untuk tiap ruangan.

$$
P_{\text {ruangan }}=\sum_{\text {tipe lampu }} P_{\text {lampu }} \times N_{\text {lampu per ruangan }}
$$

b) Kami kemudian kalikan hasil tahap 1 dengan data pada tabel 9 pada ruangan yang bersesuaian, sehingga didapat total penggunaan listrik dalam Watt-hour pada tiap ruangannya selama bulan Januari. Penghitungan tahap ini didasarkan pada persamaan (2-1) pada studi pustaka

$$
W_{\text {ruangan }}=P_{\text {ruangan }} x t_{\text {ruangan }}
$$

c) Kami kemudian jumlahkan hasil pada tahap 2 dari semua ruangan, sehingga didapat penggunaan listrik dalam Watt-hour untuk semua ruangan. Didapat hasil sebesar 2453613.75

$$
W_{\text {dalam ruangan }}=\sum_{\text {semua ruangan }} W_{\text {ruangan }}=2453613.75
$$

d) Kemudian kami menyiapkan penggunaan energi untuk lampu di luar ruangan dengan cara mengalikan daya per jenis lampu dengan kuantitas untuk jenis lampu yang ada di luar ruangan. Kemudian dikalikan lagi dengan banyaknya jam aktif lampu. Asumsinya lampu yang letaknya di luar ruangan menyala selama 14 jam sehari selama hari kerja. Karna hanya ditemukan 1 jenis lampu di luar ruangan, didapat perhitungan sebagai berikut: 
$N_{\text {lampu luar ruangan }} * P_{\text {lampu }} *$ jam kerja $*$ jumlah hari kerja $=W_{\text {luar ruangan }}$

Keterangan

$N_{\text {lampu luar ruangan }}=$ Banyaknya lampu di luar ruangan

$P_{\text {lampu }}=$ Daya per lampu sesuai jenis lampu

$$
459 \times 10,5 \times 14 \times(31-4)=1366328,25 \mathrm{Wh}
$$

e) Kemudian jumlahkan penggunaan listrik untuk penerangan ruangan dan non-ruangan, sehingga didapat penggunaan listrik sektor penerangan pada gedung Griya Legita pada kasus lampu hanya nyala apabila digunakan.

$$
\begin{aligned}
& W_{\text {dalam ruangan }}+W_{\text {luar ruangan }}=W_{\text {total }} \\
& 1366328,25+2453613.75=3819942 \mathrm{Wh}
\end{aligned}
$$

f) Bandingkan dengan data pengeluaran listrik per bulan pada sektor penerangan gedung Griya Legita. Hitung seberapa efisien metode lampu yang terjadwal secara otomatis apabila diimplementasikan. Rumus Efisiensi adalah sebagai berikut

$$
\begin{gathered}
\text { Efficiency }=\frac{\Delta W}{W_{\text {saat ini }}}=\frac{W_{\text {saat ini }}-W_{\text {total dengan sistem }}}{W_{\text {saat ini }}} \\
\frac{63515000-3819942}{63515000}=0.93986
\end{gathered}
$$

\subsection{Hasil}

Berdasarkan analisis yang kami buat, hasil menunjukkan persentase efisien $93.986 \%$. Meski dirasa sangat efektif, kami merasa bahwa persentase ini terlalu besar. Hal ini diduga karena data penggunaan listrik yang kami dapat belum saling rasional satu sama lain. Salah satunya data penggunaan listrik dengan data banyaknya lampu. Mari kita coba hitung total watt lampu apabila semua lampu dinyalakan 24 jam selama 31 hari.

$$
\sum_{\text {semua tipe lampu }} P_{\text {lampu }} * N_{\text {lampu }} * 24 * 31
$$

$$
(789 * 10.5+240 * 18+6 * 10.5) * 24 * 31=9424620 \mathrm{Wh}
$$

Perhatikan bahwa hasil hitungan semua lampu ketika nyala 24 jam sebulan penuh masih belum mencapai pengeluaran yang terdata pada data pengeluaran listrik dari pihak rektorat. Ini membuktikan masih adanya komponen-komponen penerangan yang belum kami perhitungkan juga dayanya.

Alternatif lain penghitungan efisiensi adalah dengan cara menghitung pengurangan dari penggunaan energi lampu di griya legita yang dinyalakan 14 jam sehari dan penggunaan energi lampu di griya legita yang menggunakan lampu terjadwal otomatis, lalu pengurangan tersebut dijadikan persen terhadap data pengeluaran energi dari rektorat.

$$
\begin{aligned}
& \frac{W_{\text {lampu } 14 \text { jam per hari }}-W_{\text {total dengan sistem }}}{63515000} * 100 \%=\text { Efisiensi } \\
& \frac{(789 * 10.5+240 * 18+6 * 10.5) * 14 *(31-4)-3819942}{63515000} * 100 \%=1.524636699 \%
\end{aligned}
$$


Didapat pengurangan penggunaan listrik sebesar $1.5 \%$ apabila kita menggunakan perhitungan kedua. Meskipun terlalu sedikit, nilai 1.5 persen tetap terhitung besar untuk pengeluaran energi sebesar $63.515 \mathrm{kwh}$.

\section{KESIMPULAN}

Dari hasil analisis penelitian ini, maka dapat disimpulkan bahwa metode penggunaan lampu secara terjadwal otomatis dapat mengurangi konsumsi daya listrik di Gedung Griya Legita Universitas Pertamina. Hal ini dapat didukung dari hasil analisis yang menunjukan ada sebanyak $93.986 \%$ yang membuktikan bahwa jumlah konsumsi listrik untuk penggunaan lampu secara terjadwal otomatis lebih efisien dibandingkan dengan penggunaan lampu secara manual. Apabila daya lampu (konsumsi listrik) yang dikeluarkan lebih sedikit, maka biaya pengeluaran untuk penerangan per bulannya akan lebih sedikit juga. Tetapi, data yang kami peroleh belum cukup akurat karena apabila data daya yang kami peroleh diasumsikan digunakan 24 jam dalam 31 hari masih belum sesuai dengan data pengeluaran penerangan yang kami dapatkan dari pihak rektorat. Oleh karena itu, efisiensi perbandingan lampu secara terjadwal otomatis dengan lampu secara manual yang kami dapatkan masih belum cukup optimal, dikarenakan data daya lampu dan kuantitas lampu yang kami dapatkan kemungkinan masih ada yang belum kami perhitungkan. Tetapi, saat diasumsikan adanya pengurangan dari penggunaan energi lampu di griya legita yang dinyalakan 14 jam sehari dan penggunaan energi lampu di griya legita yang menggunakan lampu secara terjadwal otomatis maka akan didapatkan persentase efisiensi penggunaan lampu $1.5 \%$ atau sebanyak $63515 \mathrm{kwh}$ yang dapat dihemat per harinya. Hal ini menunjukan bahwa penggunaan lampu secara terjadwal otomatis masih terbukti lebih efisien dibandingkan dengan penggunaan lampu secara manual.

\section{DAFTAR PUSTAKA}

[1] Michael Agustinus, "Pemborosan Listrik di Gedung-gedung Pemerintah Capai 30\%," 2016. [Online]. Available: https://finance.detik.com/energi/d-3176383/pemborosan-listrik-di-gedung-gedungpemerintah-capai-30. [Accessed: 01-Mar-2019].

[2] Y. Yanuar, "85 Persen Konsumsi Listrik Rumah Tangga Habis untuk Barang Ini - Bisnis Tempo.co," 2017. [Online]. Available: https://bisnis.tempo.co/read/1036800/85-persen-konsumsi-listrik-rumahtangga-habis-untuk-barang-ini. [Accessed: 07-Mar-2019].

[3] B. Suherman, "Efisiensi Energi Listrik Lampu Penerangan Menggunakan Sensor Inframerah Efisiensi Energi Listrik Lampu Penerangan Menggunakan Sensor Inframerah,” 2016, vol. 4, no. October, pp. $2-5$.

[4] "'HEMAT LISTRIK, YUK!" | WWF Indonesia," 2009. [Online]. Available: https://www.wwf.or.id/?10200/Hemat-listrik-Buat-apa-Kan-masih-mampu-bayar. [Accessed: 07Mar-2019].

[5] D. O. Purba, "Berbagai Upaya Pemprov DKI Tekan Konsumsi Listrik - Kompas.com," 2018. [Online]. Available: https://megapolitan.kompas.com/read/2018/03/26/10482561/berbagai-upayapemprov-dki-tekan-konsumsi-listrik. [Accessed: 07-Mar-2019].

[6] Tim Komunikasi Kementerian ESDM dan Tim Komunikasi Pemerintah Kemkominfo, "Hemat Energi 'Potong 10\%' Dorong Kesadaran Pemanfaatan Energi Bertanggung Jawab," 2017. [Online]. Available: https://kominfo.go.id/index.php/content/detail/9680/hemat-energi-potong-10-dorongkesadaran-pemanfaatan-energi-bertanggung-jawab/0/artikel_gpr. [Accessed: 07-Mar-2019].

[7] Biro Humas dan Tata Usaha Pimpinan Kementerian PPN/Bappenas dan Tim Komunikasi Pemerintah Kemkominfo, 'Hemat Energi 'Potong 10\%' Dorong Kesadaran Pemanfaatan Energi Bertanggung Jawab | bssn.go.id,” 2017. [Online]. Available: https://bssn.go.id/hemat-energi-potong-10-dorongkesadaran-pemanfaatan-energi-bertanggung-jawab/. [Accessed: 07-Mar-2019].

[8] R. Akhadiprasetyo, D. T. Mesin, F. Teknik, U. Indonesia, and I. K. Energi, “Analisis konsumsi energi pada gedung perkantoran di jakarta," pp. 1-8, 2014.

[9] D. Halliday and R. Resnick, Fundamentals of Physics: Extended Version, 9th ed. John Wiley \& Sons, 2010.

[10] F. M. Rubinstein and M. Karayel, "The Measured Energy Savings from Two Lighting Control Strategies," IEEE Trans. Ind. Appl., vol. IA-20, no. 5, pp. 1189-1197, 1984.

[11] A. Hidayat, "Pengertian dan Penjelasan Penelitian Kuantitatif - Lengkap - Uji Statistik," 2012. [Online]. Available: https://www.statistikian.com/2012/10/penelitian-kuantitatif.html/amp. [Accessed: 07-Mar-2019]. 